\title{
ANALYSIS OF LANDSCAPE ELEMENTS THAT AFFECT PROPERTY VALUE BASED ON THE PERCEPTION OF HOUSING RESIDENTS IN SURABAYA
}

\author{
Nita Setiawati Wibisono ${ }^{1^{*}}$, Timoticin Kwanda ${ }^{2}$, Njo Anastasia $^{3}$ \\ ${ }^{1}$ Department of Master Program in Civil Engineering, Petra Christian University, \\ ${ }^{2}$ Department of Architecture, Petra Christian University, \\ ${ }^{3}$ Department of Finance, Petra Christian University, \\ Jalan Siwalankerto 121-131, Surabaya 60236, INDONESIA \\ *Corresponding author; Email: nita91.wibisono@gmail.com
}

\begin{abstract}
This research is done to determine landscape elements that affect property value based on housing residents' perception in Surabaya residential areas. The landscape elements that used in this research are natural elements such as vegetation and soil; and man-made element such as garden statue, road pattern, road width and hierarchy, park and plant, artificial lake, and road equipment. Purposive sampling technique is used to represent respondents in the residential areas that provide landscape elements in East and West Surabaya. Data analysis technique uses validity and reliability test, analysis factor, binary logistic regression, and the average of variable test. The result shows that majority of the residents of East Surabaya and West Surabaya residential areas approved that landscape consist of park and plant, road width and hierarchies, and road pattern affect their residential property values. The residents are also willing to contribute about $7.4 \%$ of their house price to improve the appearance of the residential landscape.
\end{abstract}

Keywords: Perception; landscape elements; residential; and property value.

\section{INTRODUCTION}

As the second biggest city after Jakarta, in 2014 the population in Surabaya has reached more than 2.853.661 people (Badan Pusat Statistik, 2014), and subsequently development of new residential areas in Surabaya is needed as the number of people increas every year (Fikriyah and Wisnu, 2013). Based on a research by Ghana and Navastara (2012), this urban phenomenon happens in big cities such as Surabaya, as demand of housing keeps increasing as the basic needs of society. Consequently, in 1990s large scale new housing development in Surabaya is quite fast that developed in East Surabaya, such as the development of Pantai Timur Surabaya by Dharmala Grup, Sac Nusantara, and Pakuwon Jati (Kwanda, 1999). Similarly in West Surabaya, large scale new housing development are also developed for example Graha Family, Pakuwon City, Citra Raya, and Pakuwon Indah. These new residential areas that provide comprehensive amenities can influence house price, like some lots that near the pond and golf course in Graha Family and Citra Raya are more expensive than the regular lots, and some lots in Pakuwon Indah and Laguna Indah are also more expensive that near the facilities (Kwanda, Chandra \& Wijaya, 2002). Such conditions lead housing residents to participate for procurement and maintenance of the facilities including landscape elements in the residential area. This notion is confirmed by Helfand, Park, Nassauer \& Kosek, (2006) in their research that housing occupants in Michigan have willingness to pay in order to get better environment through the procurement of native plants.

The other previous researches have also shown that elements of landscape design consists of fountain, gazebo, vegetation, bench, pergola, railing, and park can influence house value in Malaysia, because it gives a comfortable and safety feeling (Hussain et al, 2014). In line with the previous research, this study focuses on landscape elements in Surabaya by adding some elements such as shape and color of the vegetation, and road equipment. The purpose of this research is to find landscape elements which influenced property value significantly based on perception of housing residents in East and West Surabaya, and to find out how much in percentage that housing residents are willing to contribute for procuring and maintaining landscape elements in their residential areas.

\section{LANDSCAPE ELEMENTS AND PERCEPTION}

Starke and Simonds (2013) stated that landscape with specific characteristics could be enjoyed by the entire human senses and joined together in harmony with nature to strengthen the landscape characteristic. 
Landscape design is one of the most important elements in residential design because it can make genius loci that give safety feeling and comfort (Hussain et al, 2014). In other words, residential landscape does not only provide view, but also the benefits of relaxation for housing residents, accordingly the combination of shape and function of residential landscape are the most important thing. According to Ashihara (1981), landscape elements are divided into two categories namely soft material that consists of vegetation, and hard material that consists of pavement, road, pergola, and road equipment for instance bench, road lighting, and signage.

Similar to Ashihara (1981), in general, landscape elements are divided into 2 factors, namely natural and man-made factors, and according to various studies each factor comprise the following:

1. Natural factor, such as:

a. Vegetation type and size that can influence property value, shape refers to plant's outline to achieve design concept, color of flora can make people focus on landscape area, and texture can affect sense of scale (Niemiera, 2009);

b. Soil quality is determined by organic matter that contained in the top layer that has high nutrition and fertile (Koenig and Isaman, 2010).

2. Man-made factor, such as:

a. Garden statues that can be used as appeal and vocal point of landscape (Ye, 2009);

b. Road pattern such as grid pattern can make geometric shape to generate effective lots, curved pattern is more effective if applies to contoured roads, and cul-de-sac pattern can make houses to have higher privacy (Joseph and Lee, 1975);

c. Road width and hierarchies such as primary and secondary artery roads that connects city's main road with the entrance road to the residential area (8 meter wide per two lanes), primary and secondary collector roads that connects main road in the residence area with the entrance roads of the housing blocks ( 7 meter wide per two lanes), primary and secondary local roads that connects road in the housing block with 6 meter wide per two lanes (Kwanda, et al, 2002);

d. Green park and open space can be the most important things in attracting buyers $(\mathrm{Ng}$, 2005), and park can give positive impact to feeling and relaxation (Ye, 2009);

e. Water bodies is used as aesthetic and ecosystem (Krankina, et al, 2008);

f. Service facilities that near to houses can make residents to feel comfortable (Ye, 2009).
In addition, human's perception of landscape's quality that is the level of residents' satisfaction can be created through interaction and knowledge about landscape (Nasar, 1988). Accordingly, Niemiera (2009) states that landscape design, vegetation size and type that use in residential environment could increase property value significantly, and even house price can increase $10 \%$ to $12 \%$ when landscape is improvised (Elam \& Stigarll, 2012).

\section{RESEARCH METHODS}

This study is a quantitative approach that aims to test the model, establish the fact, show the relationship between variables, provide a statistical description and figure out the result. This research hypothesis required that landscape elements do influence property value based on the perception of housing residents in East and West Surabaya residential areas. The population of this research is residents of housing areas in East and West Surabaya, and the following Lemeshow, Hosmer \& Lwangsa (1997) formula is used in order to estimate the sample size (96 respondents):

$\mathrm{n}=\mathrm{Z}_{1-\alpha / 2 \mathrm{x}}^{2} \mathrm{P}[1-\mathrm{P}] / \mathrm{d}^{2}$

Where: $\mathrm{n}=$ sample sizes, for $\mathrm{Z}$ (95\% confidence) $=$ 1.960 and $\alpha=5 \%$, for $\mathrm{P}$ (proportion) $=0.5$, and for $\mathrm{d}$ (sampling error) $=0.01$.

The sampling technique of this research is purposive sampling, which is done by selecting newly developed residential areas in East and West Surabaya that have already equipped with landscape elements. Data were obtained by distributing questionnaires to the residents that used the Likert scale (15). All statistical analyses were performed using of Statistical Package for the Social Sciences (SPSS) software, version 23.0 through some statistical tests namely:

1. Validity test, the variables are valid if number of $r$ in corrected item-total correlation is higher than $r$ table.

2. Reliability test, the variables are reliable if the score of Cronbach's Alpha is higher than 0.70 (Nunnaly \& Bernstein, 1994).

3. Factor analysis is used to find the correlation between the similar variables.

4. Binomial logistic regression analysis is used to determine how much the influence of each landscape elements to property value based on perception of the housing residents.

5. Average test analysis is used to determine the tendency of perception and opinion of housing residents about existence and condition of landscape elements in residential area in East and West Surabaya. 


\section{RESULTS AND DISCUSSION}

The required data were collected from December 2015 to June 2016, and in total, there are 103 respondents, 51 respondents are residents who live in East Surabaya such as Pakuwon City, Regency 21, Pantai Mentari, Puri Galaxy, and Galaxy Bumi Permai, and 52 respondents are residents in West Surabaya area such as Citraland, Pakuwon Indah, Wisata Bukit Mas phase 1 and 2, Villa Bukit Mas, Royal Regency, Prambanan Residence, Darmo Hill, Bukit Darmo Golf, Dian Istana, and Graha Family residence. Based on these respondents, the residents were characterized as mostly self-employed with their ages are around 46-55 years old, and they have lived in the residential areas from 1999 to 2015. Validity and reliability test were done, and variable that does not eligible is loop road pattern, hence it was deleted and the validity test is repeated until all of the variables are valid, then the reliability test is carried out.

The result showed that the data was reliable, because score in Cronbach's Alpha table is higher than 0.7. For factor analysis, variables that used are park and vegetation, road pattern, statue, road width and hierarchies, and road equipment, and the result of factor analysis is as follows (Table 1):

1. Park and vegetation variable: value of KMO MSA

(Kaiser-Meyer-Olkin Measure of Sampling Adequacy) is 0.818 higher than 0.50 , and significant, so it can be used as value factor. The output result shows that this factor can explain the variance in the mount of $42.28 \%$

2. Road pattern variable: value of KMO MSA is 0.610 higher than 0.50 , and significant, so it can be used as value factor. The output result shows that this factor can explain the variance in the mount of $48.45 \%$

3. Garden statue variable: value of KMO MSA is 0.50 , and significant, so it can be used as value factor. The output result shows that this factor can explain the variance in the mount of $84.30 \%$

4. Road width and hierarchies variables: value of KMO MSA is 0.773 higher than 0.50 , and significant, so it can be used as value factor. The output result shows that this factor can explain the variance in the mount of $73.94 \%$

5. Artificial lake variable: value of KMO MSA is 0.663 higher than 0.50 , and significant, so it can be used as value factor. The output result shows that this factor can explain the variance in the mount of $70.07 \%$

6. Road equipment variable: value of KMO MSA is 0.640 higher than 0.50 , and significant, so it can be used as value factor. The output result shows that this factor can explain the variance in the mount of $50.97 \%$

Table 1. Result of factor analysis

\begin{tabular}{|c|c|c|c|}
\hline Variable & $\begin{array}{c}\text { KMO and } \\
\text { Bartlett's score }\end{array}$ & $\begin{array}{l}\text { Variance } \\
(\%)\end{array}$ & Significant \\
\hline Park and vegetation & .818 & 42.283 & .000 \\
\hline $\begin{array}{l}\text { Road pattern and } \\
\text { hierarchies }\end{array}$ & .610 & 48.449 & .000 \\
\hline Statue & .500 & 84.302 & .000 \\
\hline Road width & .773 & 73.937 & .000 \\
\hline Artificial Lake & .663 & 70.071 & .000 \\
\hline Road equipment & .640 & 50.967 & .000 \\
\hline
\end{tabular}

After each factor can be found, then analysis can be continued with binomial logistic regression model as follows:

$\mathrm{y}=\alpha+\beta_{1} \mathrm{X}_{1}+\beta_{2} \mathrm{X}_{2}+\beta_{3} \mathrm{X}_{3}+\beta_{4} \mathrm{X}_{4}+\beta_{5} \mathrm{X}_{5}+$

$\beta_{6} X_{6}+\epsilon$

Where:

$\mathrm{y}=$ perception value

$\alpha=$ constant

$\beta=$ value

$\mathrm{X}_{1}=$ park and vegetation variable

$\mathrm{X}_{2}=$ road pattern and hierarchies variable

$\mathrm{X}_{3}=$ garden statue variable

$\mathrm{X}_{4}=$ road width

$\mathrm{X}_{5}=$ artificial lake variable

$\mathrm{X}_{6}=$ road equipment variable

$\epsilon=$ error

The result of the analysis is shown in Table 2, as three variables are not significant such as road pattern, garden statue, and road equipment, thus the model of binomial logistic regression analysis is:

$\mathrm{Y}=1.119+0.914$ PARK + 0.666 HIERCH +

1.178 POND

The result of binomial logistic regression can be seen by odds ratio to find how likely the affect of independent variables on dependent variable. If odds ratio is equal to 1 , there is a chance around $50 \%$ of the house residents agree that landscape elements can affect property value. Based on the perception of house residents, three variables have the odds ratio score $>1$, the odds ratio score of park and plant variable is 2.494 that means this variable can increase property value up to $71.3 \%(2.494: 3.494=0.713)$. The odds ratio score of road width and hierarchies variables is 1.947 that means this variable can increase property value up to $66 \%(1.947: 2.947=$ 0.66 ). The odds ratio score of artificial lake variable is 3.247 that means this variable can increase property value up to $76 \%(3.247: 4.247=0.764)$. 
Table 2. Result of Binomial Logistic Regression

\begin{tabular}{|c|c|c|c|c|}
\hline Variable & $\beta$ & $\begin{array}{l}\text { Odds } \\
\text { Ratio }\end{array}$ & $P$ value & $\begin{array}{c}\text { Significant } \\
(\mathrm{p} \text { value }< \\
0.05)\end{array}$ \\
\hline $\begin{array}{l}\text { Park and vegetation } \\
\text { (PARK) }\end{array}$ & 0.914 & 2.494 & .008 & $\sqrt{ }$ \\
\hline Road pattern (PTTRN) & -.195 & .823 & .498 & $\mathrm{X}$ \\
\hline Garden Statue (STATUE) & -.363 & .696 & .256 & $\mathrm{X}$ \\
\hline $\begin{array}{l}\text { Road width and } \\
\text { hierarchies (HIERCH) }\end{array}$ & .666 & 1.947 & .039 & $\sqrt{ }$ \\
\hline Artificial lake (POND) & 1.178 & 3.247 & .002 & $\sqrt{ }$ \\
\hline Road equipment (ACC) & -.160 & .852 & .658 & $\mathrm{X}$ \\
\hline Constant & 1.119 & & & \\
\hline
\end{tabular}

The mean value of each factor close to 4 , it indicates respondents agreed that landscape elements in East and West Surabaya residential areas have been given care and treated well (Table 3). The striking differences in mean value between the two residential areas are park and plant, road pattern, garden statue, and road width and hierarchies. Based on the respondents, in East Surabaya areas such as Pakuwon City, park and vegetation tend to be more maintained (3.73 versus 3.50 ), road width tends to be wider (3.96 versus 3.72), and road equipment that consist of signage, lighting, cleanliness of the road are better (3.90 versus 3.81) than in West Surabaya residential area.

Respondents in West Surabaya are more interested in road pattern than in East Surabaya for dynamic curve road pattern was applied to contour landforms condition at Citraland residential area (3.76 versus 3.50), and they are more interested in garden statues (3.74 versus 3.39 ), for there are many garden statues in the areas that can be used as appeal and orientation for the area. Artificial lake in West Surabaya residential for example in Citraland residence is slightly better than in East Surabaya such as Pakuwon City residence for it was made larger as part the drainage system to contain rainwater.

Table 4 represents the respondent's average of willingness to pay for a better landscape in West Surabaya is slightly lower than in East Surabaya. It is caused by the environment in East Surabaya residential tend to be flat and dry, consequently housing residents are willing to give contribution to make the residential environment more beautiful.

Table 3. Difference Average Score between Residential Area in East and West Surabaya

\begin{tabular}{lcc}
\hline Variable & East Surabaya & West Surabaya \\
\hline Park and vegetation & 3.73 & 3.50 \\
Road pattern & 3.50 & 3.76 \\
Garden statue & 3.39 & 3.74 \\
Road width and hierarchies & 3.96 & 3.72 \\
Artificial lake & 3.11 & 3.13 \\
Road equipments & 3.90 & 3.81 \\
\hline
\end{tabular}

Table 4. Difference Willingness to Pay

\begin{tabular}{lc}
\hline Area & \% Willingness to Pay \\
\hline East Surabaya & $7.63 \%$ \\
West Surabaya & $7.15 \%$ \\
\hline
\end{tabular}

\section{CONCLUSION}

Nowadays, people have paid attention to the environment issues where they live as they believe that good environment can improve their quality of life. Based on the discussion, in general we may conclude that property value in East and West Surabaya residential areas is influenced by landscape elements based on the judgment of housing residents $(67 \%)$. In details, the property value in the housing areas is influenced significantly by three landscape elements namely park and plant, road width, and artificial lake. Housing residents are willing to pay more for $7.4 \%$ of their house price to build and maintenance landscape elements in order to beautify the residential environment. For further studies, this research suggests that:

1. For further research, other factors can be added namely social and cultural factors, land area, building area, the appearance of houses, landscape design, and public facilities such as club house, worship places, shopping area, and education area. Social and cultural factors are daily activities that carried out regularly by housing resident, accordingly it can be the characteristic in that area.

2. For developers, the quality and quantity of landscape elements in residential area can be more improved, especially the three elements namely park and floras, road width, and artificial lake. Developers are expected to be more attentive to housing residents on the importance of landscape elements that relates to the increase of property value.

3. Housing residents should be asked to collaborate with developers in maintaining the landscape elements to keep the environment neat and clean including the residential amenities. This suggestion is supported by the research result that the majority of housing residents have willingness to pay up to $7.4 \%$ of their house price for a better environment.

\section{REFERENCES}

Ashihara, Y. (1981). Exterior Design in Architecture, Revised Edition. New York: Van Nostrand Reinhold.

Badan Pusat Statistik (2014). Banyaknya penduduk menurut jenis kelamin hasil registrasi tahun 2008-2014. Retrieved August, 2015, from https://Surabayakota.BPS.Go.Id 
Elam, E. \& Stigarll, A. (2012). "Landscape and House Appearance Impacts on the Price of Single-Family Houses", Journal of Environmental Horticulture, 30(4), pp. 182-188.

Fikriyah, S. \& Wisnu (2013). "Perkembangan Kawasan Real Estate di Surabaya Barat Tahun 1970-2000: Kontribusi Citraland dalam Perkembangan Kawasan Real Estate di Surabaya Barat", AVATARA E-Journal Pendidikan Sejarah, 1(3), pp. 503-518.

Ghana, A.K. \& Navastara, A. M. (2012). "Pengaruh Perkembangan Permukiman terhadap Dinamika Harga Lahan di Surabaya", Jurnal Teknik POMITS, 1, pp.1-8.

Hussain, Mohd Ramzi Mohd., Shahli, Firtynadia Mohd., Tukiman, Izawati \& Zen, Ismawi $\mathrm{Hj}$. (2014). "The Impact of Landscape Design on House Prices and Values in Residential Development in Urban Areas", APCBEE Procedia, 10, pp. 316 - 320.

Helfand, G.E., Park, J.S., Nassauer, J.I. \& Kosek, S. (2006). "The Economics of Native Plants in Residential Landscape Designs", Lanscape and Urban Planning, 78, pp. 229 - 240.

Joseph, C. \& K, Lee. (1975). Urban Planning and Design Criteria. New York: Van Nostrand Reinhold Company.

Koenig, R. \& Isaman, V. (2010). "Topsoil Quality Guidelines for Landscaping", Digital Commons Paper, 15.

Krankina, O. N. et al. (2008). "Meeting The Challenge of Mapping Peatlands with Remotely Sensed Data", Biogeosciences Discussions, European Geosciences Union, 5(3), pp. 20752101.
Kwanda, T. (1999). "Peranan Perencanaan Fisik dalam Pengembangan Permukiman Skala Besar Pantai Timur Surabaya", Dimensi Teknik Arsitektur, 27(1), pp. 1-7.

Kwanda, T. Chandra, H.P. \& Wijaya, S.V. (2002). "Studi Tentang Perencanaan Tapak dan Analisis Pengaruh Lebar Jalan terhadap Luas dan Harga Jual Kapling pada Beberapa Perumahan di Surabaya", Dimensi Teknik Arsitektur, 30(1), pp. 27-38.

Lemeshow S, Hoemer, D.W., Klar, J. \& Lwangsa, S.K. (1997). "A Comparison of Goodness-ofFit-Test for the Logistic Regression Model", Statistic in Medicine, 16, pp. 965-980.

Nasar, J. L. (1988). Environmental Aesthetics: Theory, Research, and Applications. New York: Cambridge University Press.

Ng, A. (2005). "Gamuda Offers a Vast Expanse of Green Home Buyers", The Star, January 17.

Niemiera, A. X. (2009). "The Effect of Landscape Plants on Perceived Value", Virginia Cooperative Extension Publication, 426-087, pp.1-3. Retrieved August, 2015, from https://www.pubs. ext.vt.edu/426/426-087/426-087.html.

Nunnaly, J. C. \& Bernstein, I. H. (1994). Psychometric Theory, $3^{\text {rd }}$ edition. New York: McGraw Hill.

Starke, B. \& Simonds, J. O. (2013). Landscape Architecture: A Manual of Environmental Planning and Design, 5th edition. New York: McGraw-Hill Education.

Ye, Jienan (2009). "Research of Landscape Design in Residential Area", The European Spatial Planning Programme, 13. 